\title{
ROLA OECD JAKO AKTORA PUBLICZNEJ POLITYKI EDUKACYJNEJ
}

\begin{abstract}
The role of the OECD as an actor in public education policy

The article was written on the basis of literature review. It shows the activities of the OECD as a public policy actor whose activity leads to the increase of the quality of teaching processes. OECD did not solve, however, many problems resulting from the cultural diversity of countries at which it directs its activities. The OECD membership countries presented in the case study have been developed based on an analysis of the literature and materials of this organization.

The author emphasizes the significant role of the OECD as a public policy actor in improving the quality of teaching. At the same time, the author points out that systemic solutions do not work the same in all countries, whether developed or developing.
\end{abstract}

Keywords: public policy, pedagogical supervision, education policy

\section{Streszczenie}

Artykuł został napisany na podstawie przeglądu literatury przedmiotu. Pokazuje działania OECD jako aktora polityki publicznej, którego działalność prowadzi do wzrostu jakości procesów nauczania. OECD nie rozwiązała jednak wielu problemów wynikających z różnorodności kulturowych krajów, do których kieruje swoje działania. Przy prezentacji desk research krajów członkowskich OECD korzystano z literatury i materiałów tej organizacji.

Autorka podkreśla znaczącą rolę OECD jako aktora polityki publicznej w podnoszeniu jakości nauczania. Jednocześnie zwraca uwagę, że rozwiązania systemowe nie działają tak samo we wszystkich państwach, zarówno rozwiniętych, jak i rozwijających się.

Słowa kluczowe: polityki publiczne, nadzór pedagogiczny, polityka edukacyjna

\section{Wprowadzenie}

Podejmując tematykę polityki publicznej, należy podkreślić, że jest to stosunkowo nowa dziedzina nauki. Wywodzi się ze Stanów Zjednoczonych oraz anglosaskiej tradycji pragmatyzmu i empiryzmu. Politykę publiczną cechuje podejście 
wielodyscyplinarne. Koncentruje się ona na określonym problemie - stanowi on przedmiot analiz, zmierzających do próby jego rozwiązania. Nauka o polityce publicznej zakorzeniona jest $\mathrm{w}$ wartościach humanistycznych, ponieważ dostrzega grupy społeczne, które wyjaśniają problem zgodnie z wartościami, jakimi się kierują [Cochran, Malone, 2014]. W Polsce minister nauki i szkolnictwa wyższego w 2011 roku wyodrębnił nauki o polityce publicznej jako samodzielną dyscyplinę, dzięki czemu niektóre uczelnie podjęły trud rozwoju specjalności naukowej w tym obszarze.

Polityka publiczna może być opisywana jako działania rządu zmierzające do osiągnięcia określonych celów publicznych i uwzględniające opinię społeczną. Ich głównym celem jest rozwiązywanie problemów publicznych, które w danym momencie uznawane są za najważniejsze. Polityka publiczna stoi na straży powiązań między rządem a obywatelami. Obejmuje kluczowe aspekty dotyczące zdefiniowania problemu, następnie określenia celu, który ma zostać osiągnięty, oraz doboru odpowiednich instrumentów politycznych służących realizacji zadania. Polityka publiczna stała się sercem, duszą i tożsamością wszystkich rządów [Cochran, Malone, 2014].

Przedmiotem badań nad polityką publiczną są przede wszystkim zróżnicowani aktorzy instytucjonalni oraz procesy decyzyjne, procesy formułowania celów, procesy równoważenia interesów, zadań oraz ich wdrażanie, a także relacje, jakie zachodzą między tymi procesami. Celem jest dostarczanie twórcom i realizatorom polityki publicznej wiedzy wynikającej z prowadzonych badań dotykających problematyki edukacyjnej, społecznej i ekonomicznej, ze szczególnym uwzględnieniem wymiaru, który bezpośrednio łączy się z obywatelami i instytucjami wykonującymi zadania publiczne [Woźnicki, 2012].

\section{OECD jako aktor edukacyjnej polityki publicznej}

Współczesne polityki publiczne są wypracowywane i realizowane przez wielu aktorów. Jednym z nich jest Organizacja Współpracy Gospodarczej i Rozwoju utworzona na mocy Konwencji o Organizacji Współpracy Gospodarczej i Rozwoju 14 grudnia 1960 roku. Początkowo konwencję podpisało 17 państw Europy Zachodniej oraz Stany Zjednoczone, Kanada i Turcja. Obecnie w skład OECD wchodzi 35 krajów, ale ze swoją działalnością i badaniami dociera ona do 100 państw [OECD, online b].

Należą do niej głównie kraje demokratyczne i wysoko rozwinięte. Początkowo celem OECD było skonsolidowanie wspólnoty atlantyckiej, która stała przed wieloma wyzwaniami ekonomicznymi. Kolejnym zadaniem była praca na rzecz krajów słabiej rozwiniętych. Obecnie zasadniczym dążeniem OECD jest wspieranie państw członkowskich w osiąganiu jak najwyższego poziomu wzrostu gospodarczego oraz podnoszenie stopy życiowej obywateli. Pomocne ma być $\mathrm{w}$ tym wprowadzanie wspólnych reguł, wytycznych i norm działania w poszczególnych dziedzinach gospodarki. Jedną z najważniejszych jest zasada równości wszystkich 
członków, niezależnie od wkładu finansowego czy potencjału. Polska jest pełnoprawnym członkiem OECD od 22 listopada 1996 roku. W wymianie międzynarodowej jest traktowana jako równorzędny partner, co przynosi jej wymierne korzyści ekonomiczne [OECD, online a].

OECD jako aktor edukacyjnej polityki publicznej podjęła się opracowania i wdrożenia działań nakierowanych na podnoszenie jakości nauczania i wykorzystanie dostępnych danych na ten temat [OECD, 2009]. Ewaluacja, czyli rzetelne monitorowanie i ocenianie zebranego materiału [Prawelska-Skrzypek, 2017: 7], stała się najważniejszym narzędziem służącym do zrozumienia zachodzących procesów uczenia i nauczania. Leszek Korporowicz [2016: 10] zwrócił uwagę, że ewaluacja uwzględnia trzy wymiary: racjonalność celu, metodę jej prowadzenia i sposób zastosowania. Bezpośrednio dotyczy ona uczniów, pracy nauczycieli, działalności dyrektorów, szkół oraz systemów edukacyjnych. Po zakończonej ewaluacji sporządzany jest raport zawierający informacje na temat mocnych i słabych stron badanej placówki oświatowej. Dostęp do wniosków zawartych w raporcie mają wszystkie zainteresowane strony. OECD [2009] przyznaje, że nadal istnieją państwa, które nie podejmują działań ewaluacyjnych, nie wskazując, co jest tego powodem.

Warto zwrócić uwagę, że zaprojektowanie efektywnego systemu ewaluacji nie jest łatwe. Wymaga od edukacyjnej polityki publicznej, której istotnym aktorem jest OECD, rzetelnej diagnozy popartej dowodami w postaci badań. Łączy się to z możliwością realizowania wielu eksperymentów oraz wdrażania programów pilotażowych [OECD, 2013].

\section{Edukacyjna polityka publiczna w krajach rozwijających się}

Polityka publiczna jest odpowiedzią na rozmaite problemy, z jakimi boryka się społeczeństwo. Niejednokrotnie złożoność tej problematyki sprawia, że trudno znaleźć właściwe rozwiązania [Zybała, 2013: 13]. Twórcy polityki edukacyjnej zwracają uwagę na znaczenie systematycznie prowadzonej ewaluacji szkolnictwa, kontroli działalności nauczycieli oraz dyrektorów placówek oświatowych. Istotne jest monitorowanie postępów edukacyjnych dziecka. Wyniki prowadzonych obserwacji stają się informacją zwrotną pomagającą utrzymać system szkolnictwa na wysokim poziomie [OECD, 2013].

\section{Brazylia}

Andréia da Cunha Malheiros Santana i José Carlos Rothen [2015: 90] pokazują, że charakterystyczną cechą publicznej polityki edukacyjnej w Brazylii jest model kształcenia ustawicznego opracowywany na podstawie wyników testów i wywiadów przeprowadzanych z dyrektorem oraz nauczycielami. W Brazylii nadzór nad szkolnictwem sprawuje rząd, a konkretnie powołany przy nim 
Sekretariat Edukacji. Do zadań Sekretariatu należy prezentowanie wyników zewnętrznej kontroli dotyczącej skuteczności funkcjonowania szkół oraz wskazywanie obszarów, które wymagają poprawy. W celu podniesienia poziomu edukacji publicznej wprowadzono coroczne testy przeprowadzane wśród uczniów na każdym poziomie nauczania. Ich wyniki służą do porównywania osiągnięć uczniów z różnych szkół. Dzięki temu edukacyjna polityka publiczna może się przekładać na wyższą jakość procesów edukacyjnych w brazylijskim szkolnictwie [Santana, Rothen, 2015].

Santana i Rothen [2015] porównali funkcjonowanie dwóch szkół, które podczas ewaluacji zewnętrznej osiągnęły dwa różne wyniki (A i B). Szkoła, która uzyskała wyższy stopień (A) w ewaluacji zewnętrznej, znajduje się na obrzeżach miasta, w starym, nobliwym sąsiedztwie. Tylko $8 \%$ młodzieży, która do niej uczęszcza, potrzebuje wsparcia ekonomicznego od państwa. W placówce na umowę publiczną zatrudnionych jest $61 \%$ nauczycieli, którzy wykonują swój zawód dłużej niż pięć lat, co może wskazywać na ich mniejszą rotację, a co za tym idzie - większą skuteczność nauczania. Przy czym $45 \%$ nauczycieli ukończyło prestiżowe studia [Santana, Rothen, 2015: 95]. Szkoła, która uzyskała stopień B w ewaluacji zewnętrznej, znajduje się w centrum miasta. Aż 70\% uczęszczającej do tej placówki młodzieży otrzymuje od rządu pomoc materialną. Rodzice uczniów nie angażują się w życie szkoły i nie czują się zintegrowani. Dzieci często przenoszone są ze szkoły do szkoły ze względu na brak stałego miejsca zamieszkania. W omawianej placówce pracuje wielu nowych nauczycieli, co świadczy o dużej rotacji pracowników, wśród których tylko 11\% ukończyło studia [Santana, Rothen, 2015].

Obie szkoły są zobligowane do realizacji tej samej polityki edukacyjnej i podlegają tym samym zewnętrznym ocenom. Ujednolicenie wymogów stawianych różnym szkołom często sprawia, że podejmowany trud nie odpowiada potrzebom społecznym. W kraju dostrzega się zróżnicowanie poziomów nauczania uczniów w tych samych typach szkół. Opisywany przykład pokazuje, że systemowe rozwiązania stosowane wszędzie na identycznych zasadach nie sprawdzają się w publicznej polityce edukacyjnej Brazylii [Santana, Rothen, 2015].

\section{Indie}

W ramach publicznej polityki edukacyjnej w Indiach szczególną uwagę zwraca się na różnice intelektualne pomiędzy dziećmi, które kształcą się w przedszkolach i szkołach publicznych, a dziećmi uczącymi się w prywatnych placówkach oświatowych. Badania prowadzone przez Abhijeet Singh [2014: 31] z Uniwersytetu Oksfordzkiego w Wielkiej Brytanii wykazały, że uczniowie zapisywani do szkół prywatnych osiągają lepsze wyniki edukacyjne niż dzieci ze szkół rządowych.

Jedną z głównych przyczyn obserwowanych różnic wśród dzieci w wieku szkolnym jest jakość edukacji na poziomie przedszkolnym. W Indiach publiczne przedszkola mają zróżnicowany poziom nauczania, ponieważ edukacja na tym etapie jest nieformalna. Placówki przedszkolne stanowią tzw. ochronkę (wczesny 
ośrodek opieki nad dziećmi). Wspierane są przez rząd, ale ich głównym celem jest dokarmianie dzieci i kontrolowanie stanu ich zdrowia.

Inaczej wygląda to $\mathrm{w}$ przedszkolach prywatnych. Zatrudniani są w nich nauczyciele, którzy systematycznie prowadzą zaplanowane zajęcia edukacyjne. Badania prowadzone przez Pratham w 2013 roku wykazały, że 30\% dzieci z wiosek zapisanych jest do prywatnych przedszkoli i szkół podstawowych [Pratham, 2013: 51]. Rozpowszechniony prywatny system kształcenia powoduje, że rząd w Indiach oszczędza pieniądze na szkolnictwie państwowym. Oszczędności powinien jednak inwestować $\mathrm{w}$ podnoszenie jakości usług $\mathrm{w}$ istniejących placówkach rządowych, ponieważ różnice między sektorem publicznym a prywatnym stale się pogłębiają [Singh, 2014].

\section{Edukacyjna polityka publiczna w krajach rozwiniętych}

\section{Holandia}

Edukacyjna polityka publiczna Holandii, tworzona na podstawie rekomendacji OECD, znacznie różni się od działań podejmowanych w Brazylii i Indiach. Odmienność ta spowodowana jest m.in. czynnikami ekonomicznymi i kulturowymi. Z raportu opublikowanego przez Ministerstwo Edukacji [Scheerens i in., 2012] wynika, że holenderska konstytucja zapewnia system edukacji oparty na zasadzie wolności. Organizacje, po spełnieniu podstawowych wymagań określonych dla placówek edukacyjnych, mogą zyskać status szkoły. Rodzice samodzielnie podejmują decyzję, do której szkoły będzie uczęszczało ich dziecko. Obecnie Holandia uznawana jest za kraj, w którym autonomia szkół jest na najwyższym poziomie. Zaprzestano ewaluacji programów, a skoncentrowano się na systemowych zmianach. Pomimo dużej autonomii pozostano przy ujednoliconych egzaminach końcowych zamykających poszczególne etapy edukacyjne obowiązujące we wszystkich typach szkół, a Ministerstwo Edukacji nadal nadzoruje wprowadzanie najnowszych modeli kształcenia [Scheerens i in., 2012: 6-13].

W Holandii ewaluacją zajmują się specjalnie do tego powołane organizacje, które dysponują technicznymi umiejętnościami badawczymi. Głównymi instrumentami wewnętrznej polityki jakościowej szkoły są samoocena szkolna oraz kontrole szkolne. Każda szkoła dokonuje podsumowania corocznych wyników egzaminacyjnych, jakości opieki oraz wyników prowadzonej kontroli. Od 2008 roku przeprowadza się powszechną kontrolę szkół, której celem jest sprawdzenie jakości kształcenia. Jeśli szkoła jest sklasyfikowana jako (bardzo) słaba, wówczas intensyfikuje się i kontrolę, i działania poprawiające jej funkcjonowanie. Jeśli działania naprawcze prowadzone w szkole nie przyniosą oczekiwanych rezultatów, placówka może zostać zamknięta [Scheerens i in., 2012]. 


\section{Stany Zjednoczone Ameryki Północnej}

Edukacyjna polityka publiczna w Stanach Zjednoczonych, jak pisze Susan Brookhart [2013], zależna jest od polityki prowadzonej na szczeblu federalnym, stanowym i lokalnym. Działania podejmowane w kierunku polepszania jakości nauczania w szkołach amerykańskich opierały się na wynikach uzyskiwanych z testów, które miały na celu przydzielenie uczniów do poszczególnych kategorii i ich selekcjonowanie. Polityka publiczna koncentrowała się na budynkach, zarządzaniu i wskaźnikach uzyskiwanych przez uczniów.

W 2010 roku opublikowano zestaw standardów edukacyjnych w celu zminimalizowania konkurencyjności i rywalizacji pomiędzy placówkami oświatowymi. Istotne było upowszechnienie wymagań i rozciągnięcie ich na wszystkie stany tak, aby uczniowie byli przygotowani na sukces w globalnej gospodarce i społeczeństwie [Brookhart, 2013].

Tymczasem magazyn „Phi Dela Kappan” [Why School?..., 2016] podaje, że w 2016 roku przeprowadzono ankietę wśród 1221 dorosłych, pytając o jakość amerykańskiej edukacji. $Z$ badań wynika, że największym problemem jest brak wystarczających funduszy przeznaczanych na szkolnictwo [Why School?..., 2016: 14-15].

\section{Edukacyjna polityka publiczna prowadzona w Polsce}

Postęp cywilizacyjny obserwowany na całym świecie wpłynął także na zmiany w edukacyjnej polityce publicznej prowadzonej w Polsce. Pod koniec lat dziewięćdziesiątych XX wieku opracowano i wdrożono zewnętrzny system oceniania uczniów, za który odpowiada specjalnie w tym celu powołana Centralna Komisja Egzaminacyjna. Sprawdziany i egzaminy przeprowadzane są za pomocą takich samych narzędzi dla poszczególnych poziomów edukacyjnych.

Kolejną istotną innowacją było opracowanie wymagań państwa względem placówek oświatowych. Rozporządzeniem Ministra Edukacji Narodowej z dnia 7 października 2009 roku wprowadzono początkowo siedemnaście wymagań, które w 2015 i w 2017 roku zmodyfikowano i zmniejszono do dziewięciu. Są to:

Wymaganie 1: Procesy edukacyjne są zorganizowane w sposób sprzyjający uczeniu się.

Wymaganie 2: Uczniowie nabywają wiadomości i umiejętności określone w podstawie programowej.

Wymaganie 3: Uczniowie są aktywni.

Wymaganie 4: Kształtowane są postawy i respektowane normy społeczne.

Wymaganie 5: Szkoła lub placówka wspomaga rozwój uczniów z uwzględnieniem ich indywidualnej sytuacji.

Wymaganie 6: Rodzice są partnerami szkoły lub placówki. 
Wymaganie 7: Szkoła lub placówka współpracuje ze środowiskiem lokalnym na rzecz wzajemnego rozwoju.

Wymaganie 8: Szkoła lub placówka, organizując procesy edukacyjne, uwzględnia wnioski z analizy wyników egzaminu ósmoklasisty, egzaminu maturalnego, egzaminu potwierdzającego kwalifikacje w zawodzie oraz innych badań zewnętrznych i wewnętrznych.

Wymaganie 9: Zarządzanie szkołą lub placówką służy jej rozwojowi [Rozporządzenie Ministra Edukacji Narodowej..., 2017].

Obowiązujące wymagania państwa względem placówek oświatowych zostały wypracowane podczas prowadzonych dyskusji przedstawicieli różnych środowisk związanych z systemem oświaty. Wprowadzone wymagania stały się odpowiedzią na zmieniającą się rzeczywistość i mają służyć rozwojowi szkół oraz podnoszeniu jakości ich pracy, która przekłada się na osiągnięcia uczniów, a w dalszej perspektywie na rozwój całego społeczeństwa. Nadzór pedagogiczny w Polsce, prowadzony przez Ministra Edukacji Narodowej, w województwie przez kuratora, a w szkole przez dyrektora, przyjął trzy formy: ewaluacji, kontroli i wspomagania. Punktem wyjścia stało się sformułowanie jasnych, ogólnie znanych i akceptowanych celów obowiązujących dla wszystkich szkół. Celem prowadzonych ewaluacji jest demokratyczny rozwój systemu i zarządzania oświatowego oraz rozwój placówek.

Ewaluacji danej placówki dokonuje zespół ewaluatorów, którzy kontrolę w placówkach oświatowych dzielą na trzy etapy. W pierwszym ustala się wraz z dyrektorem harmonogram badania, w którym uwzględniona jest rozmowa $\mathrm{z}$ nauczycielami, uczniami, rodzicami oraz z przedstawicielami środowiska lokalnego. Kolejnym etapem jest przeprowadzenie badania ilościowego i jakościowego wśród osób tworzących społeczność szkolną. Ewaluatorzy prowadzą również obserwacje w trakcie lekcji, przerw śródlekcyjnych oraz w innych codziennych sytuacjach związanych z funkcjonowaniem szkoły. Następnie analizuje się zebrane dane i sporządza raport [Mazurkiewicz, 2012]. Wyniki ewaluacji zewnętrznej przedstawiane są radzie pedagogicznej, a następnie umieszczane na platformie internetowej www.npseo.pl. Każdy, kto jest zainteresowany treścią raportu, ma do niego swobodny dostęp.

Prowadzona w Polsce publiczna polityka edukacyjna ukazuje mocne i słabe strony funkcjonowania placówek oświatowych. Niejednokrotnie zmusza do świadomego podejmowania przemyślanych, popartych dowodami działań na rzecz poprawy jakości procesów edukacyjnych, ale jak podkreśla Grzegorz Mazurkiewicz [2011: 61], nadal zdarza się, że działania podejmowane są intuicyjnie, przez co mogą prowadzić do marginalizowania szkolnictwa.

Podsumowując, możemy stwierdzić, że działalność publicznej polityki edukacyjnej w omawianych państwach jest różnorodna i koncentruje się na różnych problemach. Powodem tego stanu rzeczy może być odmienny stopień rozwoju społecznego, ekonomicznego i kulturowego tych państw. Nie zmienia to jednak faktu, że we wszystkich krajach omawiane instytucje odpowiedzialne za szkolnictwo wkładają wiele wysiłku w doskonalenie i podnoszenie jakości procesów 
uczenia się i nauczania. Wspólnym mianownikiem dla wszystkich państw jest kształcenie młodego pokolenia w taki sposób, aby potrafiło radzić sobie w otaczającej rzeczywistości.

\section{Zakończenie}

W każdym społeczeństwie funkcjonują aktorzy polityki publicznej, którzy dbają o dostarczanie obywatelom jak najlepszej jakości usług publicznych. Ze względu na złożoność polityk nie sposób przewidzieć rezultatów proponowanych rozwiązań i wprowadzanych zmian. Dlatego też nie można zastosować tych samych rozwiązań dotyczących określonych problemów we wszystkich krajach, w których one występują [Zybała, 2013].

OECD odgrywa istotną rolę w projektowaniu i wdrażaniu rozwiązań określonych problemów, uwzględniając rozliczne wyzwania w wielu państwach. Każde podejmowane działanie naprawcze opiera się na rzetelnej, świadomej i spójnej diagnozie problemu. Osiągając konsensus, OECD zwraca uwagę, aby wszystkie zainteresowane osoby lub instytucje akceptowały racjonalne uzasadnienie wprowadzanych zmian. W związku z tym władze rządowe w każdym kraju zwiększają szanse wdrażania polityki publicznej przez poprawę komunikacji ze społeczeństwem, przedstawiając wizję zmian lub proponowanych reform [OECD, 2013].

Leszek Korporowicz [2016: 12] podkreśla, że niemal całkowicie pomija się analityczny ogląd danych ewaluacyjnych na rzecz technokratycznej wizji celów. Racjonalność prowadzonej ewaluacji traktowana jest jako konieczny element kontroli i wprowadzania zmian, nie uwzględnia ona jednak specyfiki i mentalności społecznej. Często, jak wskazuje Anna Hesse-Gawęda [2016: 423], stosowana jest z neoliberalną tendencją do porównywania konkurujących ze sobą organizacji, nie uwzględniając potrzeby poprawy pracy.

Najważniejszą zatem rolą OECD jako aktora publicznej polityki edukacyjnej powinno być zapobieganie wyeliminowaniu ewaluacji przy jednoczesnym odejściu od rankingowania na rzecz wspierania wielokulturowych społeczeństw, dla których określone działania są realizowane. Nasuwa się jednak pytanie, czy ideologia gold standard, która proponowana jest przez OECD, może znaleźć zastosowanie w tak różnych kulturowo społeczeństwach? Czy społeczeństwa powinny bezwarunkowo ufać i wdrażać działania wypracowane przez OECD? Pytania te pozostają otwarte i mogą wyznaczać dalsze kierunku badań w tej materii. 


\section{Bibliografia}

Brookhart S.M. (2013), The Public Understanding of Assessment in Educational Reform in the United States, „Oxford Review of Education”, 39(1), 52-71.

Cochran Ch.L., Malone E. (2014), Public Policy: Perspectives and Choices, $5^{\text {th }}$ ed., Lynne Rienner Publishers, Boulder (Colo.).

Hesse-Gawęda A. (2016), How Polish Schools Use Information from External Examinations System for Development: The Results of School Evaluation [w:] L. Gómez Chova, A. López Martínez, I. Candel Torres (red.), INTED 2016 Proceedings: 10 ${ }^{\text {th }}$ International Technology, Education and Development Conference (s. 418-423), IATED Academy, Valencia.

Korporowicz L. (2016), Ewaluacja w spoteczeństwie polskim, „Uniwersyteckie Czasopismo Socjologiczne", 15(2), 7-13.

Mazurkiewicz G. (2011), Przywództwo edukacyjne. Odpowiedzialne zarzadzanie edukacja wobec wyzwań współczesności, Wydawnictwo Uniwersytetu Jagiellońskiego, Kraków.

Mazurkiewicz G. (2012), Ewaluacja $w$ nadzorze pedagogicznym. Zasady $i$ wartości [w:] G. Mazurkiewicz (red.), Jak być jeszcze lepszym? Ewaluacja w edukacji (s. 13-35), Wydawnictwo Uniwersytetu Jagiellońskiego, Kraków.

OECD (2009), School Evaluation: Current Practises in OECD Countries and a Literature Review, EDU/WKP(2009)21 (EDU Working Paper No. 42).

OECD (2013), Synergies for Better Learning: An International Perspective on Evaluation and Assessment, OECD Publishing, Paris.

Pratham (2013), Annual Status of Education Report 2012, Technical report, Pratham, New Delhi.

Prawelska-Skrzypek G. (2017), Wstęp [w:] G. Prawelska-Skrzypek (red.), Ewaluacja w procesie tworzenia i realizacji polityki naukowej i innowacyjnej (s. 7-11), Polska Akademia Nauk, Dom Wydawniczy Elipsa, Warszawa.

Santana A.C.M., Rothen J.C. (2015), The External Evaluation of Schools and the Ongoing Teacher Education: The Case of the State of São Paulo, „Revista Diálogo Educacional”, 15(44), 89-110.

Scheerens J., Ehren M., Sleegers P., Leeuw R. (2012), Country Background Report for the Netherlands, Evaluation and Assessment Frameworks for Improving School Outcomes, University of Twenty, Publishing OECD, Netherlands, 1-101.

Singh A. (2014), Test Score Gaps Between Private and Government Sector Students at School Entry in India, „Oxford Review of Education”, 40(1), 30-49.

Why School? The 48 th Annual PDK Poll of the Public's Attitudes Toward the Public Schools (2016), „Phi Delta Kappan”, 98(1) (Supplement).

Woźnicki J. (2012), Nowa dyscyplina - nauki o polityce publicznej usytuowana $w$ dziedzinie nauk społecznych, „Nauka” (Poznań), 1, 133-151.

Zybała A. (2013), Problem złożoności w politykach publicznych, „Zoon Politikon”, 4 (Między ideami, interesami a instytucjami. Polityki publiczne w praktyce. Nauka o ,przezwyciężaniu trudności”), 13-27. 


\section{Źródła internetowe}

OECD, online a, http://www.oecd.org/about/ [dostęp: 13.05.2018].

OECD, online b, http://www.oecd.org/about/history/ [dostęp: 13.05.2018].

Rozporządzenie Ministra Edukacji Narodowej z dnia 11 sierpnia 2017 r. w sprawie wymagań wobec szkół i placówek, http://dziennikustaw.gov.pl/du/2017/1611/1 [dostęp: 13.05.2018]. 